\title{
Comparative Performance Evaluation Of Bullock Drawn Maize Planters
}

\author{
Raghvendra Sachan \\ Department of Farm Machinery and Power Engineering \\ SV College of Agricultural Engineering and Technology \& \\ Research Station \\ IGKV, Raipur - 492012, Chhattisgarh, India
}

\author{
S V Jogdand \\ Department of Farm Machinery and Power Engineering \\ SV College of Agricultural Engineering and Technology \& \\ Research Station \\ IGKV, Raipur - 492012, Chhattisgarh, India
}

\begin{abstract}
This study was carried out during winter season of 2015-16 at Sant Kabir College of Agriculture and Research Station, Kabirdham (CG). A single row maize planter and three row inclined plate planter were compared for laboratory test and field test. In lab testing seed rate of both planters were found as $26.34 \mathrm{~kg} \mathrm{ha}^{-1}$ and $27.65 \mathrm{~kg} \mathrm{ha}^{-1}$, respectively. The theoretical seed rate $\left(\mathbf{R}_{\mathrm{st}}\right)$ and the seeding mass rate $\left(\mathbf{R}_{\mathrm{sm}}\right)$ of a single row maize planter and three row inclined plate planter were found as 74074 seeds ha-1, 83333 seeds ha-1 and $19.3 \mathrm{~kg} \mathrm{ha}$ 1, $21.7 \mathrm{~kg} \mathrm{ha}^{-1}$ respectively. Draught, operation speed, power requirement, depth of seed placement, field efficiency and effective field capacity of both planters were recorded as 56.89 kgf, $1.32 \mathrm{~km} \mathrm{~h}^{-1}, 0.204 \mathrm{~kW}, 5.56 \mathrm{~cm}, 68.33 \%, 0.041 \mathrm{ha} \mathrm{h}^{-1}$ and $47.54 \mathrm{kgf}, 1.50 \mathrm{~km} \mathrm{~h}^{-1}, 0.194 \mathrm{~kW}, 5.44 \mathrm{~cm}, 66.66 \%, 0.12 \mathrm{ha} \mathrm{h}^{-1}$ respectively where the theoretical field capacity was found to be 0.06 and $0.18 \mathrm{ha} \mathrm{h}^{-1}$, respectively.
\end{abstract}

Keywords- Maize, single row maize planter, three row inclined plate planter, draught, power requirement

\section{INTRODUCTION}

Maize in Chhattisgarh is one of major cereal crop as it contributes (102.70 area in thousand hectares which have production 177.82 thousand MT and productivity $1655 \mathrm{~kg}$ per hectare in Kharif and 30.88 area in thousand hectares which have production 50.18 thousand MT and productivity $1624.90 \mathrm{~kg}$ per hectare in rabi) in the year 2012-2013 (Directorate of Agriculture, Raipur).

It is basically grown in Sarguja and Jagdalpur region. In Sarguja district of Chhattisgarh maize is highly preferable by the farmers after rice. Sarguja contributes 12272 thousand hectares area and the productivity of maize in Sarguja district is $2200 \mathrm{~kg}$ per hectare, production is about $26.99 \mathrm{Mt}$ in the year 2012-2013 (Deputy Director of Agriculture, Ambikapur).

Chhattisgarh has the total geographical area 137.9 lakh hectare, in which 46.04 percent forest, 4641 thousand hectare area kharif cropped, 1542 thousand hectare area rabi cropped. Chhattisgarh has average annual rainfall 1200-1300 mm. (Banjare, 2015). Animals are the largest contributor of farm power in India and yet, the major source of marginal, small and even medium farmers who account for more than $80 \%$ of total agricultural holding and $40 \%$ of total cultivated land (Nirala, 2011). Planters are used for row drilling (hill dropping) or check row planting of larger seeds than those which normally go through seed drills. They give more accurate results with larger seeds. They may be tractor operated or animal drawn. In the state of Chhattisgarh the average height of bullocks is less as compared to other states and most of the field operations are done by bullocks. So a single row maize planter and three row inclined plate planter are taken to the performing in the field.

\section{MATERIALS AND METHODS}

The study was carried out during winter seasons of 2016 at Sant Kabir College of Agriculture and Research Station, Kabirdham (CG).

Table 1. Specification of planters

\begin{tabular}{|c|c|c|}
\hline Particulars & $\begin{array}{c}\text { Single row maize } \\
\text { planter }\end{array}$ & $\begin{array}{c}\text { Three row inclined } \\
\text { plate planter }\end{array}$ \\
\hline Length, mm & 2614 & 1820 \\
\hline Width, mm & 790 & 1270 \\
\hline Height, mm & 475 & 940 \\
\hline Weight, $\mathrm{kg}$ & 7.5 & 80 \\
\hline Number of rows & 1 & 3 \\
\hline Power source & Pair of bullock & Pair of bullock \\
\hline Developed by & $\begin{array}{c}\text { SVCAET and RS, } \\
\text { IGKV, Raipur }\end{array}$ & C.I.A.E. Bhopal \\
\hline
\end{tabular}

\section{Planters}

A single row maize planter (Fig 1) and bullock drawn three row inclined plate planter (Fig 2) were used for sowing of maize crop where combinations of various tillage operations were done.

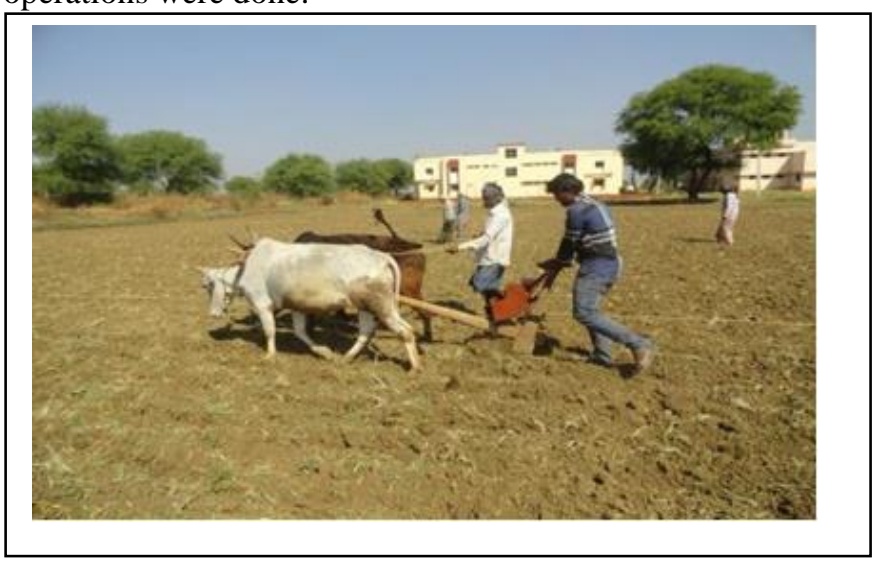

Fig 1. Single row maize planter 


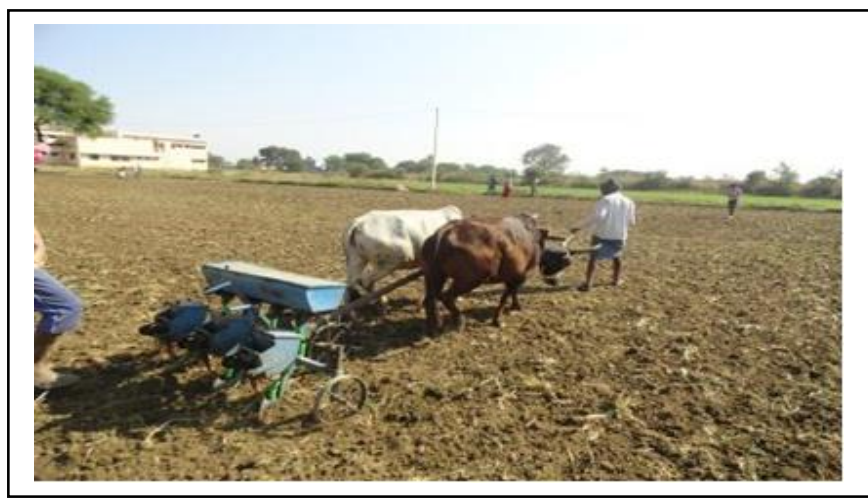

Fig 2. Three row inclined plate planter

\section{Laboratory test}

\section{Calibration of maize planters}

A single row maize planter and three row inclined plate planter were calibrated according to the IS: 8956-1981 test code of planter.

\section{Theoretical seeding rate (Rst)}

The number of maize seeds planted per hectare was calculated by using the following relationship (Bakhtiari and Loghavi, 2009):

$$
\mathrm{R}_{\mathrm{st}}=\frac{10000 \times 10000}{W \times X s}
$$

Where,

$$
\begin{aligned}
& \text { Rst = Theoretical seeding rate, seeds } \mathrm{ha}^{-1} \text {; } \\
& \mathrm{W}=\text { Row width }, \mathrm{cm} \text {; and } \\
& \mathrm{Xs}=\text { Seed spacing along the row, } \mathrm{cm} .
\end{aligned}
$$

\section{Seeding mass rate (Rsm)}

The total mass of maize seeds planted per hectare expressed in $\mathrm{Mg} \mathrm{ha}^{-1}$ was calculated by using the following relationship (Bakhtiari and Loghavi, 2009):

$$
\mathrm{R}_{\mathrm{sm}}=\frac{M}{W \times X s} \times 100
$$

Where,

$$
\begin{aligned}
& \text { Rsm = Seeding mass rate, } \mathrm{Mg} \mathrm{ha} \mathrm{h}^{-1} \\
& \mathrm{M}=\text { Average mass of one seed, } \mathrm{g} \\
& \mathrm{W}=\text { Row width, } \mathrm{cm} \text {; and } \\
& \text { Xs = Seed spacing along the row, } \mathrm{cm} \text {. }
\end{aligned}
$$

\section{Field-test}

The 3-row inclined plate planter and a single row maize planter were tested in the field at Sant Kabir College of Agriculture and Research Station, Kabirdham (CG) during the month of February, 2016 for sowing of maize. The shape of field was rectangular and the area of each plot was $40 \times 11$ $\mathrm{m}^{2}$.

\section{Draught of maize planters}

If the line of pull through the dynamometer is not horizontal, measure the angle which the line of pull makes with the horizontal and calculate the horizontal component (draught) by the following formula (IS: 11235 - 1985):

$$
\mathrm{D}=\mathrm{P} \operatorname{Cos} \theta
$$

Where,

$\mathrm{D}=$ Draught, $\mathrm{kg}$

$\mathrm{P}=$ Pull (dynamometer reading), $\mathrm{kg}$;

$\theta=$ Angel between line of pull and horizontal, degrees.

Operating speed of maize planters

The speed of operation of planter was determined in test plots by putting two marks $30 \mathrm{~m}$ apart (A \& B). The time was recorded with the help of stop watch to travel the distance of $30 \mathrm{~m}$. The speed of operation was calculated in $\mathrm{km} \mathrm{h}^{-1}$ as given below:

Where,

$$
\mathrm{S}=3.6 \mathrm{x} \text { distances traveled }(\mathrm{m}) / \mathrm{T}
$$

$\mathrm{S}=$ Speed of operation, $\mathrm{km} \mathrm{h}^{-1}$

$\mathrm{T}=$ Time needed to cover $30 \mathrm{~m}$ distance, $\mathrm{sec}$.

Power requirement of maize planters

The power requirement was determined from the draught and speed of operation using the relation (IS: 11235 - 1985):

$$
\mathrm{HP}=\frac{\text { Draft }(\mathrm{kg}) \times \text { Speed }\left(\mathrm{m} \mathrm{s}^{-1}\right)}{75}
$$

\section{Theoretical field capacity (TFC)}

It is the actual area covered by the implement, based on $100 \%$ of time at the rated speed and covering $100 \%$ of its rated width. Field capacity was calculated by following expression (Bainer et al., 1960):

TFC $\left(\right.$ ha h $\left.^{-1}\right)=(\mathrm{W} \times \mathrm{S}) / 10$

Where,

$\mathrm{W}=$ Theoretical width of implement, $\mathrm{m}$;

$\mathrm{S}=$ Speed of operation, $\mathrm{km} \mathrm{h}^{-1}$.

Effective field capacity (EFC)

The actual field capacity is the actual rate of coverage by the implement. The total time required to complete the operation was recorded and effective field capacity was calculated followed (IS 6288-1971):

$$
\mathrm{EFC}=\frac{A}{T}
$$

Where,

$\mathrm{EFC}=$ Effective field capacity, ha $\mathrm{h}^{-1}$;

$\mathrm{A}=$ Actual area covered by implement, ha;

$\mathrm{T}=$ Effective time, $\mathrm{h}$.

Field efficiency

The field efficiency is the ratio of effective field capacity to the theoretical field capacity and expressed in $\%$.

Field efficiency $=$ EFC $/$ TFC $\times 100$

Where,

$$
\begin{aligned}
& \mathrm{EFC}=\text { Effective field capacity } \\
& \mathrm{TFC}=\text { Theoretical field capacity }
\end{aligned}
$$

\section{RESULTS AND DISCUSSION}

The observations and results obtained during the study are presented in this chapter.

Testing of the maize planters

Laboratory Test

Calibration of planters 
In lab testing seed rate of a single row maize planter and three row inclined plate planter were found as $26.34 \mathrm{~kg}$ ha-1 (74074 seeds ha-1) and $27.65 \mathrm{~kg}$ ha-1 (83333.33 seeds ha-1), respectively.

Theoretical seeding rate (Rst)

The number of maize seeds planted per hectare was calculated by using the following relationship;

$$
\mathrm{R}_{\mathrm{st}}=\frac{10000 \times 10000}{W \times X_{s}}=\frac{10000 \times 10000}{45 \times 30}
$$

$=74074.07 \approx 74074$ seeds ha $^{-1}$ (for single row maize planter)

$$
\begin{aligned}
& \mathrm{R}_{\mathrm{st}}=\frac{10000 \times 10000}{W \times X_{s}}=\frac{10000 \times 10000}{40 \times 30} \\
& =83333.33 \approx 83333 \text { seeds } \mathrm{ha}^{-1} \text { (for three row }
\end{aligned}
$$
inclined plate planter)

Where,

$$
\begin{aligned}
& \text { Rst = Theoretical seeding rate }\left(\text { No. of seeds ha }{ }^{-1}\right) \\
& \text { W = Row width }(\mathrm{cm}) ; \text { and } \\
& \text { Xs = Seed spacing along the row }(\mathrm{cm})
\end{aligned}
$$

Seeding mass rate (Rsm)

The total mass of maize seeds planted per hectare expressed in $\mathrm{Mg} \mathrm{ha}^{-1}$ was calculated by using the following relationship;

$$
\mathrm{R}_{\mathrm{sm}}=\frac{M}{W \times X_{s}} \times 100=\frac{0.26}{45 \times 30} \times 100
$$
maize planter)

$=0.0193 \mathrm{Mg} \mathrm{ha}^{-1}=19.3 \mathrm{~kg} \mathrm{ha}^{-1}$ (for single row

$$
\begin{aligned}
& \mathrm{R}_{\mathrm{sm}}=\frac{M}{W \times X_{S}} \times \mathbf{1 0 0}=\frac{\mathbf{0 . 2 6}}{\mathbf{4 0 \times 3 0}} \times \mathbf{1 0 0} \\
& =0.0217 \mathrm{Mg} \mathrm{ha}^{-1}=21.7 \mathrm{~kg} \mathrm{ha}^{-1} \text { (for three row }
\end{aligned}
$$
inclined plate planter)

Where,

$$
\begin{aligned}
& \text { Rsm = Seeding mass rate, } \mathrm{Mg} \mathrm{ha}^{-1} \\
& \mathrm{M}=\text { Average mass of one seed, } \mathrm{g} ; \\
& \mathrm{W}=\text { Row width, } \mathrm{cm} ; \text { and } \\
& \mathrm{Xs}=\text { Seed spacing along the row, } \mathrm{cm} .
\end{aligned}
$$

Field-test

The planters were field tested for their mechanical and functional performances in field area of 0.10 ha.

Draught of maize planters

The average draught was recorded of single row maize planter and three row inclined plate planter was $56.89 \mathrm{kgf}$ and $47.54 \mathrm{kgf}$ for maize, respectively.

\section{Operating Speed of maize planters}

The average speed of operation for sowing was found to be 1.32 and $1.50 \mathrm{~km} \mathrm{~h}^{-1}$ respectively, for both the planters.

\section{Power requirement of maize planters}

The average power required for single row maize planter and three row inclined plate planter was found to be $0.204 \mathrm{~kW}$ (0.27 hp) and $0.194 \mathrm{~kW}(0.26 \mathrm{hp})$ (Table 2).

Table 2. Draught, Speed of operation and Power requirement of maize

\begin{tabular}{|c|c|c|c|c|c|}
\hline $\begin{array}{c}\text { Treatmen } \\
\mathbf{t}\end{array}$ & Draught & & $\begin{array}{c}\text { Speed of } \\
\text { operation } \\
\left(\mathbf{m ~ s}^{-1}\right)\end{array}$ & \multicolumn{2}{|c|}{$\begin{array}{c}\text { Power } \\
\text { requirement }\end{array}$} \\
\hline & $(\mathbf{N})$ & $(\mathbf{k g f})$ & & $(\mathbf{k W})$ & $(\mathbf{h p})$ \\
\hline $\mathrm{T} 1$ & 558.16 & 56.89 & 0.37 & 0.204 & 0.27 \\
\hline $\mathrm{T} 2$ & 466.45 & 47.54 & 0.42 & 0.194 & 0.26 \\
\hline
\end{tabular}

\section{Field capacity and field efficiency}

The field efficiency was calculated using standard method as described earlier and results are presented in (Table 3 ).

Table 3. Field performance results of planters during planting operation

\begin{tabular}{|l|c|c|}
\hline \multirow{2}{*}{ Particulars } & \multicolumn{2}{|c|}{ Data of field performance } \\
\cline { 2 - 3 } & $\begin{array}{c}\text { Single row maize } \\
\text { planter }\end{array}$ & $\begin{array}{c}\text { Three row inclined } \\
\text { plate planter }\end{array}$ \\
\hline Travelling speed, $\mathrm{km} \mathrm{h}^{-1}$. & 1.32 & 1.50 \\
\hline $\begin{array}{l}\text { Theoretical field capacity, } \\
\mathrm{ha} \mathrm{h}^{-1} \text {. }\end{array}$ & 0.06 & 0.18 \\
\hline $\begin{array}{l}\text { Effective field capacity, ha } \\
\mathrm{h}^{-1} \text {. }\end{array}$ & 0.041 & 0.12 \\
\hline Field efficiency, \% & 68.33 & 66.66 \\
\hline
\end{tabular}

The effective field capacity of single row maize planter and three row inclined plate planter were found to be 0.041 and 0.12 ha $\mathrm{h}^{-1}$, respectively, whereas the theoretical field capacity was found to be 0.06 and 0.18 ha $h^{-1}$, respectively. From the effective and theoretical field capacity, the field efficiency of both planters was calculated as 68.33 and 66.66 $\%$, respectively.

\section{ACKNOWLEDGMENT}

Author is thankful to Dr. S.V. Jogdand, Professor, Department of Farm Machinery and Power Engineering, Swami Vivekananda College of Agricultural Engineering and Technology and Research Station, Faculty of Agricultural Engineering, IGKV, Raipur (Chhattisgarh) India for his meticulous guidance, motivation and unconditional support for this work.

\section{REFERENCES}

[1] Anonymous. 2012. Area, production and yield of maize crop, Directorate of Agriculture, Raipur, Chhattisgarh.

[2] Anonymous. 2012. Area, production and yield of maize in Sarguja district, office of Deputy Director of Agriculture, Ambikapur, Chhattisgarh.

[3] Bakhtiari, M. R. and Loghavi M. 2009. Development and evaluation of innovative garlic clove precision planter. J. Agric. Sci. Technol, 11: 125-136.

[4] Bainer, R., Kepner, R.A. and Barger, E.L. 1960. Principles of Farm Machinery. 2nd Edition, Published by John Wiley \& Sons, Inc., New York (1960).

[5] Banjare, M. 2015. Design, development and evaluation of single row animal drawn maize planter cum fertilizer applicator as an attachment with desi plough. M. Tech. Indira Gandhi Krishi Vishwavidyalaya, Raipur (C.G.): 1.

[6] BIS 1981. Bureau of Indian Standard, Test code of planter, IS: $8956-$ 1981.

[7] BIS 1985. Bureau of Indian Standard, Test code for groundnut digger, animal drawn, IS: 11235-1985.

[8] Nirala, S.K. 2011. Performance Evaluation of Bullock Drawn Mult Crop Inclined Plate Planter.International Journal of Agricultural Engineering, 4(2): 193-199. 